\title{
Die doeltreffendheid van talentbestuursprogramme in uitgesoekte Suid-Afrikaanse organisasies
}

\author{
Authors: \\ Jo-Ann P. Gainsford ${ }^{1}$ \\ Ebben S. van Zyl ${ }^{1}$

\section{Affiliations:} \\ ${ }^{1}$ Department of Industrial \\ Psychology, University of the \\ Free State, South Africa

\section{Correspondence to:} \\ Jo-Ann P. Gainsford \\ Email: \\ gainsfordjp@ufs.ac.za \\ Postal address: \\ Flippie Groenewoud \\ Building 159, Department \\ of Industrial Psychology, \\ Internal box 23, 9999, \\ University of the Free State, \\ Bloemfontein, South Africa \\ Dates: \\ Received: 23 Mar. 2012 \\ Accepted: 26 Sept. 2012 \\ Published: 04 Dec. 2012 \\ How to cite this article: \\ Gainsford, J.P., \& Van \\ Zyl, E.S. (2012). Die \\ doeltreffendheid van \\ talentbestuursprogramme \\ in uitgesoekte Suid- \\ Afrikaanse organisasies. SA \\ Journal of Human Resource \\ Management/SA Tydskrif vir \\ Menslikehulpbronbestuur, \\ 10(2), Art. \#467, 13 pages. \\ http://dx.doi.org/10.4102/ \\ sajhrm.v10i2.467
}

Oriëntasie: Die identifisering, behoud en ontwikkeling van talent moet doeltreffend bestuur word.

Navorsingsdoelwit: Die studie het ten doel om die doeltreffendheid van bestaande talentbestuursprogramme in uitgesoekte Suid-Afrikaanse organisasies in die finansiële, vervoer- en mynbousektore te evalueer.

Motivering vir die studie: Streng wetgewing (soos regstellende aksie) en die swak ekonomiese situasie in Suid-Afrika veroorsaak dat goeie presteerders as baie waardevol beskou word en behou moet word. Indien organisasies nie oor 'n doeltreffende talentbestuursprogram beskik nie, sal hulle waarskynlik talentvolle werknemers verloor.

Navorsingsontwerp, -benadering en -metode: Hierdie studie maak van 'n kwantitatiewe navorsingsontwerp gebruik. Deur middel van toevallige steekproefneming is 117 werknemers in die onderskeie sektore ingesluit. Die ANOVA-toets en Tukey se paarsgewyse vergelykingstegniek is aangewend om die verskille tussen die drie sektore te bepaal.

Resultate: Die resultate van die studie dui daarop dat die organisasies wat aan die studie deelgeneem het grootliks al die noodsaaklike komponente in die talentbestuursprogramme insluit. Die uitsondering is egter talentbestuursagteware, wat oor die algemeen nie in die talentbestuursprogramme ingesluit is nie. Verdere resultate dui daarop dat die oorgrote meerderheid van die respondente nie baie tevrede is met die komponente van die talentbestuursprogramme in hul organisasies nie. Die respondente van die mynbousektor het die laagste tevredenheidsvlakke ten opsigte van die talentbestuursprogram getoon. Die resultate dui verder daarop dat die finansiële sektor se talentbestuursprogram meer doeltreffend as dié van die mynbousektor is.

Praktiese/bestuursimplikasies: ' $n$ Omvattende lys van komponente van ' $n$ talentbestuursprogram is ontwikkel om organisasies te ondersteun in die ontwerp en implementering van 'n doeltreffende talentbestuursprogram.

Bydrae/waardetoevoeging: Die resultate van die studie kan gebruik word om bestaande talentbestuursprogramme aan te pas.

The effectiveness of talent management programmes in selected South African organisations. Orientation: This study was driven by a need that was identified within South African organisations to establish guidelines for the implementation of an effective talent management programme.

Research purpose: The purpose of this study was to evaluate the effiency of the existing talent management programme in selected South African organisations in the financial, transport and mining sectors.

Motivation for study: Legislation and the poor economic situation in South Africa necessitate the retention of talented employees. This can be done by means of an effective talent management programme.

Research design, approach and method: The study was conducted using a quantitative research design. The ANOVA test and Tukey's Studentised Range were applied to determine differences between the three sectors with regard to the effectiveness of the talent management programmes. The sample consisted of 117 identified talented employees.

Main findings: Results of the study indicated that the organisations that participated in the study do have most of the necessary components included in their talent management programmes. The exception is talent management software, which was generally not included in the talent management programmes of the organisations. Further results indicated that, for the largest part, the respondents are not very satisfied with the components of the talent management programmes in their organisations. The respondents of the mining sector indicated the lowest satisfaction levels regarding the talent management programme. Furthermore, the financial sector's talent management programme seemed to be more effective than the mining sector's talent management programme.

Practical/managerial implications: A comprehensive list of components was developed which should be included in a talent management programme to assist organisations with the design and implementation of an effective talent management programme.

Contribution/value-add: The results of the study can be utlised to adapt existing talent management programmes. 


\section{Inleiding Kernfokus van die studie}

Die identifisering, behoud en ontwikkeling van talent behoort doeltreffend in Suid-Afrikaanse organisasies bestuur te word. Indien organisasies nie oor 'n doeltreffende talentbestuursprogram beskik nie, sal hulle waarskynlik talentvolle werknemers verloor (Gainsford, 2010).

\section{Agtergrond}

Die dinamiese aard van die globale sakewêreld in die een-entwintigste eeu plaas druk op organisasies om voortdurend uitsonderlike leierskapstalent in die mark te soek, waar die vraag verreweg die aanbod oorskry. Groot organisasies stel al hoe meer hoof-uitvoerende beamptes van buite die organisasie aan en personeelagentskappe floreer as gevolg van hierdie vraag na leierskapstalent. Die meeste groot organisasies poog om toppresteerders in diens te neem en bied hierdie persone 'n enorme vergoedingspakket aan om hulle in die organisasie te behou (Charan, Drotter \& Noel, 2001; O’Neal \& Gebauer, 2006; Ready \& Conger, 2007).

Volgens Charan et al. (2001) is die aggressiewe, en somtyds desperate, pogings om buitestaanders te werf ' $n$ teken dat die leierskaps-pyplyn in die organisasie nie aan die organisasie se verwagtinge voldoen nie. Die leierskaps-pyplyn waarvan Charan et al. (2001) melding maak, is 'n pyplyn in die organisasie wat met potensiële bestuurders gevul behoort te wees sou'n huidige bestuurder uit sy of haar pos bedank.

Dit is veral in Suid-Afrika belangrik om doeltreffende talentbestuursprogramme te implementeer aangesien navorsingsbevindinge daarop dui dat die talentpoel redelik klein is (Pauw, Oosthuizen \& Van der Westhuizen, 2008). Gesprekke met menslikehulpbron- en talentbestuurders in die finansiële, mynbou- en vervoersektore, het aan die lig gebring dat die huidige ekonomie druk op sommige organisasies plaas om poste te vries. Hierdie gevriesde poste bring mee dat slegs bestaande werknemers aansoek kan doen vir poste wat in 'n organisasie beskikbaar raak. Die probleem is tans dat die interne talentpoel vinnig besig is om op te droog en dat daar nie meer talent in organisasies beskikbaar is om poste te vul nie (cf. Hardy, 2004; Pauw et al., 2008). Verskeie navorsers en menslikehulpbronspesialiste is van mening dat individue in sekere bestuursposisies dikwels nie bevorder kan word nie omdat niemand die persoon kan opvolg nie (Pauw et al., 2008; S. Phalatse [persoonlike kommunikasie, Julie 21,2009]; A. van der Zwaard [persoonlike kommunikasie, Julie 03, 2009]; H. van Zyl [persoonlike kommunikasie, Junie 18, 2009]). Die geskiedenis van SuidAfrika bring ook verdere probleme mee wat organisasies se talentbestuursprogramme kelder. Dit gebeur dikwels dat daar wel ' $n$ talentvolle werknemer in die organisasie is wat 'n sekere pos kan vul, maar regstellende aksie verhinder dat die persoon aangestel word (Hardy, 2004; Pauw et al., 2008; S. Phalatse [persoonlike kommunikasie, Julie 21, 2009]; A. van der Zwaard [persoonlike kommunikasie, Julie 03, 2009]; H. van Zyl [persoonlike kommunikasie, Junie 18, 2009]).
Vir Suid-Afrikaanse organisasies in die finansiële, vervoeren mynbousektore is dit belangrik om ' $n$ doeltreffende talentbestuursprogram te hê omdat daar voortdurend sterk mededinging vir hierdie organisasies is om talentvolle werknemers in die organisasies te behou en nie aan die opposisie af te staan nie (Donaldson, 2006; Ellehuus, 2012; OPP, 2003; Sohail, Muneer, Tanveer \& Tariq, 2011). In die lig hiervan word die navorsingsdoelwitte van die studie vervolgens uiteengesit.

\section{Navorsingsdoelwitte}

Die primêre navorsingsdoelwit is om die doeltreffendheid van bestaande talentbestuursprogramme in uitgesoekte Suid-Afrikaanse organisasies in die finansiële, vervoer- en mynbousektore te evalueer. Hierdie doeltreffendheid berus op hoe gereeld die geïdentifiseerde komponente wat in die talentbestuursprogram teenwoordig moet wees, ingesluit is (volledigheid) en op die tevredenheid van die respondente met die onderskeie komponente.

Uit die bogenoemde primêre navorsingsdoelwit volg die spesifieke doelstellings, naamlik:

- Om deur middel van literatuurverkenning en onderhoude 'n teoretiese raamwerk te ontwikkel vir die doeltreffende bepaling van die inhoud en implementering van talentbestuursprogramme in uitgesoekte Suid-Afrikaanse organisasies in die finansiële, vervoer- en mynbousektore.

- Om deur middel van 'n nie-eksperimentele navorsingsontwerp te bepaal hoe volledig die talentbestuursprogramme is in terme van die komponente wat in uitgesoekte Suid-Afrikaanse organisasies in die finansiële, vervoer- en mynbousektore ingesluit moet word.

- Om deur middel van 'n nie-eksperimentele navorsingsontwerp te bepaal hoe tevrede geïdentifiseerde talentvolle werknemers is met die huidige talentbestuursprogramme wat deur uitgesoekte SuidAfrikaanse organisasies in die finansiële, vervoer- en mynbousektore geloods word.

- Om op grond van die bevindinge van die empiriese ondersoek die uitgesoekte Suid-Afrikaanse finansiële, vervoer- en mynbousektore in die studie met mekaar te vergelyk om verskille tussen die drie sektore ten opsigte van die doeltreffendheid van hul onderskeie talentbestuursprogramme te bepaal.

\section{Waardetoevoeging deur die studie}

Die resultate van die studie kan deur organisasies as ' $n$ riglyn gebruik word om 'n doeltreffende talentbestuursprogram te ontwikkel en te implementeer.

\section{Literatuuroorsig}

$\mathrm{Na}$ aanleiding van die eerste navorsingsdoelwit word die definisies, die aard en omvang van talentbestuursprogramme, die noodsaaklikheid van talentbestuursprogramme en vier modelle van talentbestuur kortliks bespreek. 


\section{Definisies, aard en omvang van talentbestuur}

'n Breë omskrywing van talentbestuur is die strategiese bestuur van die vloei van talent deur die organisasie (Duttagupta, n.d.). Volgens Duttagupta (n.d.) is die doel van talentbestuur om te verseker dat 'n organisasie oor voldoende talent beskik om op die regte tydstip die regte persone in die regte poste te plaas, gebaseer op strategiese organisatoriese doelwitte. Duttagupta (n.d.) noem verder dat wanneer organisasies na talentbestuur verwys, dit slegs dié werknemers met die meeste talent en die hoogste potensiaal behels.

Wellins, Smith, Paese en Erker (n.d., p. 1) definieer talentbestuur as die sisteem waar persone gewerf, ontwikkel, bevorder en behou word om die organisasie se vermoë te optimaliseer ten einde positiewe organisatoriese uitkomste in die lig van die verskuiwing van mededingende landskappe en arbeidsvereistes te verkry. Meer spesifiek, talentbestuur is ' $n$ sakeproses wat sistematies die gaping tussen die talent waaroor die organisasie beskik en die talent wat die organisasie benodig om suksesvol te wees, oorbrug. Hierdie definisie sluit die volgende komponente van talentbestuur in:

- Artikulasie van die talent wat benodig word om die organisasie se sakestrategieë uit te voer.

- Die vroeë identifisering van potensiaal binne die talentpoel van die organisasie.

- Die evaluering van die gereedheid vir bevordering van die talent in die organisasie.

- Die ontwikkeling van talent in die organisasie.

\section{Die noodsaaklikheid van talentbestuur}

Sears (2003), Hartley (2004), Donaldson (2006), Sohail et al. (2011) en Ellehuus (2012) is van mening dat alle organisasies ten alle tye werknemers met die regte vaardighede en talent benodig en dat, indien 'n organisasie wil groei, dit onontbeerlik is om talent in die organisasie te vind en op 'n gefokusde wyse te ontwikkel. Suid-Afrika is geen uitsondering nie. Burke en Kock (2008) wys daarop dat, met die huidige sosiale en ekonomiese ontwikkelingsuitdagings, algemene menslikehulpbronbestuurspraktyke waarskynlik nie voldoende sal wees om die uitdagings van transformasie en die uitvoering van die verwagte ontwikkelingsrol die hoof te bied nie. Navorsing dui daarop dat talentbestuur toegepas moet word as 'n praktyk wat menslikehulpbronbestuur aanvul om organisatoriese doelwitte te bereik (Burke \& Kock, 2008).

\section{Talentbestuursmodelle}

Ten einde talent suksesvol in die organisasie te bestuur, word ' $n$ model benodig. Die vier talentbestuursmodelle wat in die studie gebruik is, is uiteenlopend. Daar is egter sekere kernaspekte wat in al die modelle voorkom en noodsaaklik is om talent in die organisasie te ontdek, te ontwikkel en te behou, en dus talent suksesvol te bestuur. Die volgende kernaspekte kan in elke model geïdentifiseer word.
Die leierskapspyplynmodel: Om 'n basis vir leierskap te bou, vereis 'n begrip van wat die hiërargie van werk in die organisasie is. In 'n groot gedesentraliseerde organisasie bestaan die hiërargie uit ses loopbaangange of -pyplyne:

- Pyplyn 1: Van selfbestuur tot die bestuur van ander werknemers.

- Pyplyn 2: Van die bestuur van ander na die bestuur van bestuurders.

- Pyplyn 3: Van die bestuur van bestuurders na 'n funksionele bestuurder.

- Pyplyn 4: Van 'n funksionele bestuurder na 'n sakebestuurder.

- Pyplyn 5: Van 'n sakebestuurder na 'n groepsbestuurder.

- Pyplyn 6: Van 'n groepsbestuurder na 'n ondernemingsbestuurder (hoof-uitvoerende beampte).

Elkeen van hierdie pyplyne verteenwoordig ' $n$ verandering van posisie in die organisasie vir die individu - 'n volgende vlak en kompleksiteit van leierskap. Verder moet sekere nuwe vaardighede en werkswaardes in elk van hierdie pyplyne ontwikkel word aangesien die posvereistes en die tydshorisonne van die vorige pyplyne verskil. Sonder 'n proses waar bestuurders gehelp word om die vaardighede, tydshorisonne en waardes van elke toepaslike leierskapsvlak aan te neem, sal geen opleiding of mentorskap 'n beduidende impak hê nie (Charan et al., 2001).

Talentbestuursbevoegdheidsmodelle: Oehley (2007) het 'n omvattende talentbestuursbevoegdheidsmodel ontwikkel wat die vereiste lynbestuursgedrag omskryf om die talentbestuurstrategie in die organisasie suksesvol uit te voer. Hierdie bevoegdhede is geëvalueer teen die uitkomste werkstevredenheid, affektiewe toewyding en voorneme om te bedank, wat veronderstel is om 'n impak op die talentbestuursbevoegdhede te hê. Werkstevredenheid kan beskryf word as 'n gunstige of positiewe emosionele toestand wat ontstaan uit die evaluering van 'n persoon se werk of werkservaring (Quick \& Nelson, 2009). Volgens Allen en Meyer (1990) verwys affektiewe toewyding na die werknemer se emosionele gehegtheid aan die organisasie, die werknemer se vereenselwiging met die organisasie en die werknemer se betrokkenheid in die organisasie. Voorneme om te bedank verwys na werknemers se gedragsintensies en word gedefinieer as 'n bewustelike en doelbewuste gewilligheid om die organisasie te verlaat (Du Plooy \& Roodt, 2010; Tett \& Meyer, 1993; Van Schalkwyk, Du Toit, Bothma \& Rothmann, 2010).

Volgens Oehley (2007) bestaan daar 'n beduidende positiewe verband tussen die eksogene latente veranderlike talentbestuursingesteldheid en die endogene latente veranderlikes lok en werf talent, ontwikkel en hou verhoudings in stand, verskaf betekenisvolle en uitdagende werk, vergoed en beloon billik en bestuur werk-lewe-balans. Volgens Oehley (2007) en Ellehuus (2012) is talentbestuur-ingesteldheid die diepgewortelde besef dat beter talent op alle vlakke in die organisasie tot beter prestasies as dié van mededingende organisasies sal lei. Hierdie beduidende verwantskappe verskaf vir die eerste keer empiriese bewyse van die 
belangrikheid van 'n talentbestuur-ingesteldheid by lynbestuurders (Ellehuus, 2012; Oehley, 2007; Van Schalkwyk et al., 2010). Addisionele beduidende verwantskappe is gevind tussen affektiewe betrokkenheid en voorneme om te bedank, tussen organisatoriese werkstevredenheid en voorneme om te bedank en tussen lok en werf talent en organisatoriese werkstevredenheid (Oehley, 2007).

Die talentbalansstaatmodel van talentbestuur: Die derde model wat in hierdie studie bespreek word, is die talentbalansstaatmodel (People Balance Sheet). Dit word veral in die vervoersektor in Suid-Afrika gebruik. Eers word prestasiebestuur, opleiding- en ontwikkelingsrekords, psigometriese evaluasie en die loopbaanrekord van die geïdentifiseerde werknemer in ag geneem om te bepaal of die werknemer oor die nodige potensiaal beskik om as talentvol bestempel te word. Die volgende stap behels ' $n$ evaluasie van die persoon se potensiaal, loopbaanaksies, prestasie, gereedheid vir bevordering, asook pospassing. Hierna maak die personeelbeampte 'n aanbeveling by die ontwikkelingsraad rakende die geïdentifiseerde talentvolle werknemer wat prestasie, opvolgbeplanning, mentorskap, retensie-aksies en ontwikkelingsareas behels. Die ontwikkelingsraad evalueer hierdie aanbevelings en keur dit goed of af. Sodra goedkeuring van die raad ontvang is, sal die menslikehulpbrondepartement die aanbeveling uitvoer (Vervoersektor [persoonlike kommunikasie, Mei 28, 2009]; A. van der Zwaard [persoonlike kommunikasie, Julie 03, 2009]; H. van Zyl [persoonlike kommunikasie, Junie 18, 2009]).

Die talentkaart-talentbestuursmodel: Die vierde model wat in hierdie studie gebruik is, staan bekend as die talentkaart en word veral in die Suid-Afrikaanse finansiële sektor gebruik. Volgens People Tree Group (persoonlike kommunikasie, Mei 28, 2004), A. Ward (persoonlike kommunikasie, Julie 16, 2009) en Gainsford (2010) gaan die model van die veronderstelling uit dat daar geen inherente waarde in 'n persoon se vaardighede bestaan nie - die waarde word deur die konteks bepaal. Wanneer ' $n$ persoon in ' $n$ posisie geplaas word, moet daar eers 'n tydperk verloop alvorens die persoon se vaardighede waardevol in die omgewing is. Namate die omgewing of konteks verander, verander die vaardighede wat benodig word om suksesvol in die organisasie te wees. Om dus die waarde van die persoon vir die organisasie te behou, moet nuwe vaardighede ontwikkel word of die persoon moet verskuif word na 'n ander pos waar 'n beter pospassing ten opsigte van vaardighede moontlik is. Volgens hierdie model bestaan daar 9 tipes werknemers wat elk ten opsigte van prestasie en potensiaal bespreek word. Hoe hoër die werknemers se prestasie en potensiaal is, hoe groter is die talent waaroor hulle beskik.

Uit bogenoemde besprekings kan die afleiding gemaak word dat talentbestuur ' $n$ proses is wat by werwing begin en by opvolgbeplanning eindig. Die ontwikkeling van vaardighede en bevoegdhede is ' $n$ onlosmaaklike komponent van enige talentbestuursprogram. Dit is nie net noodsaaklik om die talentvolle werknemers te ontwikkel nie, maar ook om die bestuurders in die organisasie van die nodige opleiding te voorsien om die talentbestuurstrategie suksesvol uit te voer.

'n Begrip vir die hiërargie van werk in die organisasie en van die regte ingesteldheid by lynbestuurders, asook 'n sistematiese talentbestuursproses en die konteks waarbinne talentbestuur plaasvind, is kritiek. Addisioneel tot die bogenoemde is die volgende aksies wat deur Wellins et al. (n.d.) se definisie van talentbestuur beklemtoon word, naamlik dat:

- die nodige talent in die organisasie geartikuleer moet word

- talent so vroeg as moontlik ontdek moet word

- die gereedheid van talentvolle werknemers vir bevordering deurgaans gemonitor moet word

- talent ontwikkel moet word.

Na aanleiding van die tweede en die derde navorsingsdoelwitte, soos hierbo uiteengesit, word die beduidende komponente van 'n talentbestuursprogram vervolgens uitgelig.

\section{Komponente van ' $\mathrm{n}$ talentbestuursprogram}

Die komponente wat in ' $n$ talentbestuursprogram ingesluit behoort te word, vorm die grondslag vir die ontwikkeling van 'n teoretiese raamwerk vir doeltreffende talentbestuur in organisasies. Hierdie komponente is as vertrekpunt gebruik vir die ontwikkeling van die talentbestuurders se onderhoudskedule en die talentbestuursvraelys wat na die geïdentifiseerde talentvolle werknemers uitgestuur is tydens die uitvoer van hierdie studie. Die volgende komponente is uit die literatuur geïdentifiseer (Wellins \& Caver, 2006; Wellins et al., n.d.):

- Hoëpotensiaal-leierskapsontwikkelingsprogramme

- Afrigting en ontwikkeling

- Bevoegdheid/ suksesprofielanalise

- Talentbestuursprosesontwerp

- Prestasiebestuur

- Talentbestuursagteware

- Opvolgbeplanning

- Vroeë identifisering van leierskapspotensiaal

- Assessering van die gereedheid vir bevordering

- Werwing

- Retensie

- Terugvoer

- Organisatoriese verbintenis

- Vereistes vir implementering.

Wellins et al. (n.d.) is van mening dat daar 9 praktyke bestaan wat as vereistes vir die implementering van 'n doeltreffende talentbestuursprogram moet dien:

1) Begin met die uitkoms in gedagte-huidige en toekomstige organisatoriese behoeftes.

2) Senior leiers moet talent bestuur.

3) Beskik oor 'n suksesprofiel.

4) Ontwikkel 'n sistematiese en geïntegreerde benadering tot alle ontwikkelingsaktiwiteite.

5) Talentbestuur is veel meer as opvolgbeplanning.

6) Onderskei tussen potensiaal, prestasie en gereedheid. 
7) Fokus op die span.

8) Verander leiers in talentbestuurders.

9) Talentbestuur behels die regte persone in die regte poste.

$\mathrm{Na}$ aanleiding van die laaste doelwit word vervolgens gefokus op die verskille in terme van die volledigheid van komponente wat ingesluit moet word, sowel as die tevredenheid met talentbestuursprogramme van werknemers in die finansiële, vervoer- en mynbousektore.

\section{Verskille in terme van die volledigheid van komponente wat ingesluit moet word, sowel as die tevredenheid met talentbestuursprogramme in die finansiële, vervoer- en mynbousektore}

Gainsford (2010) wys daarop dat min of geen navorsing beskikbaar is oor die verskille met betrekking tot die volledigheid van komponente en die tevredenheid met talentbestuursprogramme in die finansiële, vervoeren mynbousektore nie. Soos reeds genoem, berus die doeltreffendheid van talentbestuursprogramme op hoe gereeld die geïdentifiseerde komponente wat in die talentbestuursprogram teenwoordig moet wees, ingesluit is (volledigheid) en op die tevredenheid van die respondente met die onderskeie komponente in hierdie program.

Navorsing deur Liker en Meier (2007) en L. Grobler (persoonlike kommunikasie, Julie 13, 2009) dui daarop dat die doeltreffendheid van talentbestuursprogramme in Suid-Afrikaanse organisasies oor die algemeen nie op standaard is nie en dat dit vir alle sektore geld. Volgens die navorsing behoort talentbestuursprogramme doeltreffend te wees in die sektore waar menslike hulpbronne hoog op prys gestel word. Hulle beklemtoon egter dat, alhoewel menslike hulpbronne universeel as belangrik beskou word, talentbestuursprogramme nie in alle sektore as doeltreffend beskou kan word nie.

Pauw et al. (2008) en M. van Wyk (persoonlike kommunikasie, Julie 13, 2009) beweer dat talentbestuursprogramme in die private sektor waarskynlik meer doeltreffend is as in die openbare sektor aangesien private maatskappye oor die algemeen waarskynlik meer op winsbejag en oorlewing ingestel is en dus die belangrikheid van talentidentifisering en -behoud besef.

Vervolgens word die hipoteses van die studie geformuleer.

\section{Hipoteses}

- Hipotese 1: Daar bestaan statisties beduidende verskille in die tellings behaal op die volledigheid van die komponente wat in talentbestuursprogramme in die finansiële, vervoer- en mynbousektore in die uitgesoekte Suid-Afrikaanse organisasies ingesluit moet word.

- Hipotese 2: Daar bestaan statisties beduidende verskille in die tellings behaal op die tevredenheid van die geïdentifiseerde talentvolle werknemers met die talentbestuursprogramme in die finansiële, vervoeren mynbousektore in die uitgesoekte Suid-Afrikaanse organisasies.
- Hipotese 3: Daar bestaan statisties beduidende verskille in die tellings behaal op die doeltreffendheid van die talentbestuursprogramme in die finansiële, vervoeren mynbousektore in die uitgesoekte Suid-Afrikaanse organisasies.

\section{Plan van die studie}

Die navorsingsontwerp van die studie, die resultate en 'n bespreking van die resultate wat verkry is, word vervolgens bespreek.

\section{Navorsingsontwerp Navorsingsbenadering}

Hierdie studie het 'n kwantitatiewe navorsingsbenadering gevolg deur vraelyste te gebruik. Talentbestuursvraelyste is na geïdentifiseerde talentvolle werknemers uitgestuur. Beskrywende statistiek en verskille is onder andere uit die data-analise bepaal.

\section{Navorsingsmetode}

\section{Seleksie van proefpersone en steekproefnemingsprosedure}

Niewaarskynlikheidsteekproefneming (of meer spesifiek, toevallige steekproefneming) is gebruik aangesien slegs die individue wat gedurende die studie beskikbaar was, ingesluit is. Toevallige steekproefneming impliseer dat alle beskikbare gevalle gebruik word totdat die verlangde grootte bereik word. Elke persoon het dus 'n gelyke kans om in die studie ingesluit te word (Aggarwal, 2011; Berg, 2004; Fatoki \& Chindoga, 2011; Huysamen, 1996; Neuman, 1997).

Nadat onderhoude gevoer is met 26 bestuurders van die betrokke maatskappye wat talentbestuursprogramme binne die uitgesoekte groep bedryf, is die nodige aanpassings aan die onderhoudskedule gemaak. Die aangepaste onderhoudskedule is tesame met 'n biografiese vraelys na die geïdentifiseerde werknemers in die maatskappye wat talentbestuursprogramme bedryf, gestuur. Die talentbestuurders het ongeveer 40 talentvolle werknemers (in elke organisasie) geïdentifiseer aan wie die vraelyste uitgestuur is. Die vraelyste het ten doel gehad om die doeltreffendheid van die talentbestuursprogramme in die onderskeie organisasies te evalueer.

Die totale steekproef het 117 werknemers in die onderskeie sektore ingesluit (semi-geskoolde en geskoolde werknemers). Die verdelings ten opsigte van ouderdom, geslag, huistaal en ouderdomsgroepe is relatief gelyk in die groep. Die respondente wat aan hierdie studie deelgeneem het, het oor die volgende kenmerke beskik.

Van die 117 respondente wat aan die studie deelgeneem het, kom 47 uit die finansiële sektor, 35 uit die mynbousektor en 35 uit die vervoersektor. Die grootste persentasie van die respondente in die steekproef $(48 \%)$ was langer as 10 jaar in diens van die betrokke organisasies. 'n Beduidende persentasie $(35 \%)$ het slegs 'n matrieksertifikaat. Die 
meerderheid van die respondente (56\%) is vroulik. Die grootste persentasie van die respondente het twee afhanklikes (35\%), gevolg deur $18 \%$ met een afhanklike en $18 \%$ met drie afhanklikes. Die totale steekproef het uit $29 \%$ ongetroude en $71 \%$ getroude respondente bestaan. Die oorgrote meerderheid was Afrikaanssprekend (45\%), gevolg deur 20\% Engelssprekendes.

\section{Meetinstrumente}

Talentbestuursvraelys: Die talentbestuursvraelys is ontwikkel op grond van die literatuur en onder toesig van deskundiges in die bedryfsielkundeveld. Hierdie vraelys bestaan uit 42 vrae in die vorm van driepuntskaal-tipe vrae. Die vraelys het 16 items gemeet. 'n Konsepvraelys is ontwikkel en aan spesialiste (akademici en praktisyns) gestuur om by te voeg en/of te verander. Verder is onderhoude met 26 talentbestuurders gevoer ten einde die talentbestuursvraelys verder te verfyn. Bogenoemde proses het dus tot die inhoudsen gesigsgeldigheid van die vraelys bygedra. Volgens Johnson (1997), Patton (2002) en Berg (2004) vereis die insae van verskeie navorsers tydens die ontwerp van die vraelys 'n verdere metode van intermetodiese kruisvalidasie.

Virdiedoeleindesvanhierdiestudieis talentbestuursvraelyste aan 117 geïdentifiseerde talentvolle werknemers gestuur. Die onderhoudskedule wat gebruik is vir die onderhoude met die talentbestuurders is aangepas om in die korrekte formaat as 'n vraelys aan die geïdentifiseerde werknemers uitgestuur te word. Die komponente wat uit die literatuurstudie verkry is, tesame met die onderhoude wat met die bestuur gevoer is, is as basis vir die vraelyste gebruik. Die onderhoude het ten doel gehad om te bepaal of die vraelys wat aan die werknemers uitgestuur moes word, volledig was. Indien talentbestuurders van mening was dat daar komponente ontbreek, sou die navorser hierdie voorstelle inkorporeer. Daar is geen komponente by die onderhoudskedule (en dus vraelys) gevoeg nadat die onderhoude gevoer is nie omdat geen bestuurder van mening was dat daar komponente uitgelaat was nie.

Biografiese vraelys: Die tweede vraelys wat aan die werknemers uitgestuur is, is ' $n$ biografiese vraelys met die doel om die werknemers se dienstydperk, kwalifikasies, geslag, huwelikstatus, aantal afhanklikes en huistaal weer te gee.

\section{Navorsingsprosedure}

Aangesien die studie uitgevoer is in organisasies wat landswyd verspreid is, is die meeste vraelyste elektronies uitgestuur. Respondente het dan 'n redelike tydperk gekry waarin die vraelyste voltooi en aan die navorser teruggestuur moes word. Sommige respondente wat vir die navorser bereikbaar was, het 'n hardekopie van die vraelys gekry wat per hand ingevul is.

\section{Statistiese analise}

In hierdie studie is beskrywende en inferensiële statistiek gebruik. Die statistiese ontledingstegnieke wat aangewend is, is die ANOVA-toets en Tukey se paarsgewyse vergelykingstegniek. Hierdie statistiese metodes is met behulp van die SAS (2009) rekenaarprogram ('Statistical Analysis Systems version 9.21') uitgevoer. Die $F$-statistiek is gebruik om te bepaal of beduidende verskille ( $p \leq .05$ en/of $p \leq .1$ ) bestaan.

\section{Resultate \\ Beskrywende statistiek}

\section{Volledigheid van talentbestuursprogramme soos verkry van respondente}

Die volgende tabel dui op die respondente se opinies rakende hoe gereeld elke komponent wat in ' $n$ talentbestuursprogram ingesluit behoort te wees, wel ingesluit is.

Uit Tabel 1 blyk dit dat die organisasies wat aan die studie deelgeneem het, wel die noodsaaklike komponente in die huidige talentbestuursprogramme in die organisasies insluit. Daar is egter sekere komponente wat volgens die respondente nie op 'n voortdurende basis in die talentbestuursprogram gebruik word nie.

Tabel 1 wys daarop dat slegs $27 \%$ van die respondente van mening is dat die organisasie voortdurend van talentbestuursagteware gebruik maak as 'n kritieke komponent in die talentbestuursprogram. Verder is dit $45 \%$ van die respondente se opinie dat die organisasie nie deurlopend die talentvolle werknemers in die organisasie se gereedheid vir bevordering bepaal nie. Volgens 36\% van die respondente ag talentbestuurders nie die vroeë identifisering van leierskapspotensiaal as 'n prioriteit in die organisasie nie. Tabel 1 toon verder dat $50 \%$ van die respondent aangedui het dat prestasiebestuur, afrigting, ontwikkeling en opvolgbeplanning deur hul organisasies gebruik word.

Dit is verder kommerwekkend dat $50 \%$ van die respondente genoem het dat hoëpotensiaalleierskapsontwikkelingsprogramme op 'n voortdurende basis in die organisasie gebruik word. Slegs $48 \%$ van die respondente huldig die opinie dat die ontwerp van die talentbestuursproses op 'n deurlopende basis geëvalueer word. Nog 'n probleemarea is die bevinding dat slegs $49 \%$ van die respondente beweer dat hul bestuurder skiktyd toestaan aan werknemers wat gesins- of persoonlike probleme het. Die bevinding dat lynbestuurders volgens slegs 33\% van die respondente voortdurend opgelei word om talentbestuurders te wees, kan verdere probleme vir die organisasies inhou. Ander resultate uit die studie toon dat slegs $44 \%$ van die respondente voel dat die huidige talentbestuursprogram deurgaans op spanwerk fokus. Volgens 19\% van die respondente lyk dit of die verkeerde persoon in die organisasie aangestel is, naamlik iemand wat nie aan die posvereistes voldoen nie en wat nie ontwikkelbaar is nie.

\section{Tevredenheid met talentbestuursprogramme volgens die respondente}

Die volgende tabel dui op die tevredenheid met elke komponent van die talentbestuursprogramme. 
TABEL 1: Persepsie van die respondente rakende die frekwensie van die gebruik van die komponente in ' $n$ talentbestuursprogram.

\begin{tabular}{|c|c|c|c|c|c|}
\hline Vraag & Hoe dikwels ... & Geen respons & Nooit & Soms & Voortdurend \\
\hline 1 & Word hoëpotensiaal-leierskapontwikkelingsprogramme gebruik & 0 & 6 & 44 & 50 \\
\hline 3 & Word afrigting gebruik om GTW's te ontwikkel & 0 & 4 & 44 & 52 \\
\hline 5 & $\begin{array}{l}\text { Doen u bestuurder 'n een-tot-een- objektiewe assessering en word daar na afloop van die } \\
\text { assessering aktiewe stappe gedoen om GTW's te ontwikkel }\end{array}$ & 1 & 9 & 38 & 52 \\
\hline 7 & $\begin{array}{l}\text { Gee u bestuurder reguit en eerlike terugvoer aan werknemers tydens prestasiebeoordeling } \\
\text { vir ontwikkelingsdoeleindes }\end{array}$ & 0 & 5 & 24 & 71 \\
\hline 8 & $\begin{array}{l}\text { Maak u bestuurder van vaardigheid/ suksesprofielanalise gebruik om te verseker dat die } \\
\text { regte persoon met die regte kennis, vaardighede en eienskappe die regte poste beklee }\end{array}$ & 0 & 7 & 31 & 62 \\
\hline 10 & Word die samestelling van die talentbestuursproses geëvalueer & 13 & 10 & 29 & 48 \\
\hline 12 & Is prestasiebestuur deel van die talentbestuursprogram om GTW's te beoordeel & 0 & 6 & 28 & 66 \\
\hline 14 & Word talentbestuursagteware in die organisasie gebruik & 21 & 27 & 26 & 27 \\
\hline 16 & $\begin{array}{l}\text { Word kritieke poste in die organisasie geïdentifiseer as deel van die talentbestuursprogram } \\
\text { (opvolgbeplanning) }\end{array}$ & 1 & 6 & 40 & 53 \\
\hline 18 & Word 'n spesifieke metode gebruik om die gereedheid van GTW's vir bevordering te bepaal & 2 & 11 & 34 & 53 \\
\hline 20 & Probeer u bestuurder om leierskapspotensiaal so vroeg as moontlik in die organisasie te ontdek & 3 & 5 & 31 & 62 \\
\hline 23 & $\begin{array}{l}\text { Bestee u bestuurder tyd aan die aanstelling van die regte persoon vir 'n sekere pos wanneer } \\
\text { sodanige pos vakant raak }\end{array}$ & 3 & 3 & 22 & 72 \\
\hline 24 & $\begin{array}{l}\text { Is die werwing van die beste kandidaat vir'n sekere vakante pos in die organisasie } \\
\text { topprioriteit vir u bestuurder totdat die pos gevul is }\end{array}$ & 0 & 3 & 25 & 72 \\
\hline 26 & Fokus u bestuurder op die belangrikheid van die behoud van hoëprofiel-werknemers & 1 & 7 & 36 & 56 \\
\hline 27 & Beloon u bestuurder werknemers vir uitstekende werk & 0 & 4 & 31 & 65 \\
\hline 28 & Verseker $\mathrm{u}$ bestuurder dat salarisse markverwant is wanneer dit binne sy/haar gesag val & 11 & 7 & 21 & 61 \\
\hline 29 & Staan u bestuurder skiktyd ('flexi-time') toe aan werknemers met gesins- of persoonlike probleme & 3 & 13 & 35 & 49 \\
\hline 30 & $\begin{array}{l}\text { Verseker u bestuurder dat werknemers oor toereikende hulpbronne (bv. toerusting) beskik } \\
\text { om hulle werk te doen }\end{array}$ & 1 & 1 & 21 & 78 \\
\hline 31 & Verseker u bestuurder dat die werklading voldoende is, maar nie te veel om te hanteer nie & 1 & 7 & 32 & 61 \\
\hline 32 & $\begin{array}{l}\text { Wend u bestuurder ' } n \text { poging aan om bewus te wees van gesin- en persoonlike sake wat } \\
\text { werknemers se werk kan beïnvloed }\end{array}$ & 1 & 10 & 32 & 57 \\
\hline 33 & Is $u$ bereid en daartoe in staat om tot die organisasie se sukses by te dra & 1 & 0 & 8 & 91 \\
\hline 34 & Kry die talent in die organisasie geleentheid om nuwe vaardighede te ontwikkel & 3 & 3 & 36 & 57 \\
\hline 37 & Is die senior bestuurspan betrokke by die talentbestuursproses & 3 & 8 & 25 & 65 \\
\hline 38 & Word gefokus op spanwerk in die talentbestuursprogramme & 7 & 10 & 38 & 44 \\
\hline 39 & Word sleuteltalent in die organisasie in die talentbestuursprogram ingesluit & 3 & 9 & 29 & 58 \\
\hline 40 & Word menslikehulpbronaktiwiteite geïntegreer ten einde mekaar te versterk en te bevestig & 10 & 6 & 31 & 53 \\
\hline \multirow[t]{2}{*}{41} & $\begin{array}{l}\text { Is die doelwitte en strategieë van die organisasie die motief wat die gehalte en } \\
\text { hoeveelheid talent bepaal wat die organisasie benodig }\end{array}$ & 3 & 4 & 29 & 63 \\
\hline & Omgekeerde telling & - & - & - & - \\
\hline 25 & $\begin{array}{l}\text { Lyk dit of die verkeerde persoon in die organisasie aangestel is, naamlik iemand wat nie aan die } \\
\text { vereistes van die pos voldoen nie }\end{array}$ & 0 & 15 & 66 & 19 \\
\hline
\end{tabular}

GTW's, geïdentifiseerde talentvolle werknemers.

$\dagger$, Hierdie item meet in die teenoorgestelde rigting as die ander items van die vraelys.

Volgens Tabel 2 is die algehele tevredenheid met die komponente van die talentbestuursprogramme redelik laag. Slegs $44 \%$ van die respondente is baie tevrede met die hoëpotensiaal-leierskapsontwikkelingsprogramme in die organisasies, wat 'n relatiewe lae persentasie is. Slegs $36 \%$ van die respondente is baie tevrede met die afrigtingsproses en $32 \%$ is baie tevrede met die suksesprofielanalise in die organisasie. Dit is egter kommerwekkend dat slegs 32\% van die respondente baie tevrede is met die opvolgbeplanning en dat slegs $50 \%$ baie tevrede is met die vroeë identifisering van leierskapspotensiaal in die organisasie. Daar is net drie ontwikkelingstegnieke waarmee meer as 50\% van die respondente baie tevrede is, naamlik aksieleerprojekte (62\%), eksterne kursusse of seminare (54\%) en binnenshuise klaskameropleiding (52\%), wat ook relatiewe lae vlakke van tevredenheid is.
Uit Tabel 2 blyk dit verder dat nie al die respondente die sterkte van die senior bestuurspanne op standaard ag nie. Talentoptimalisering, die katalisering van verandering, asook senior spanontwikkeling, is komponente waarmee minder as $50 \%$ van die respondente baie tevrede is.

\section{Inferensiële statistiek: Verskille tussen sektore}

Die ANOVA-toets is toegepas, met sektor as die onafhanklike veranderlike en komponentfrekwensietelling, tevredenheidstelling en doeltreffendheidstelling onderskeidelik as die afhanklike veranderlikes. Daarna is die ANOVA-toets afsonderlik toegepas op elke berekende komponenttelling as die afhanklike veranderlike en sektor as die onafhanklike veranderlike. Indien die ANOVA-toets die verskille as beduidend bewys het ( $p \leq .05$ en/of $p \leq .1)$ en die relevante onafhanklike veranderlike meer as twee kategorieë het, is Tukey se paarsgewyse vergelykingstegniek aangewend. 
TABEL 2: Tevredenheid van die respondente met die talentbestuursprogramme.

\begin{tabular}{|c|c|c|c|c|c|}
\hline Vraag & Hoe tevrede is u met ... & Geen respons & Baie ontevrede & Soms tevrede & Baie tevrede \\
\hline 2 & Die huidige hoëpotensiaal-leierskapsontwikkelings-programme in die organisasie & 0 & 15 & 42 & 44 \\
\hline \multirow[t]{2}{*}{4} & Die afrigtingsproses in die organisasie & 0 & 18 & 46 & 36 \\
\hline & Die volgende ontwikkelings-tegnieke in die organisasie: & & & & \\
\hline $6 \_1$ & Posrotasie & 13 & 24 & 32 & 31 \\
\hline $6 \_2$ & Die skep van geleenthede vir werknemers om uitdagende take uit te voer & 2 & 7 & 45 & 46 \\
\hline $6 \_3$ & Die interne mentorskap-program & 2 & 26 & 41 & 32 \\
\hline 6_4 & Aksieleerprojekte & 0 & 4 & 33 & 62 \\
\hline $6 \_5$ & Eksterne kursusse of seminare & 7 & 17 & 22 & 54 \\
\hline 6_6 & Binnenshuise klaskameropleiding & 8 & 9 & 31 & 52 \\
\hline $6 \_7$ & Universiteits- en ander onderrigprogramme & 8 & 9 & 47 & 36 \\
\hline 9 & Die gebruik van bevoegdheid of suksesprofiel-analise in die organisasie & 2 & 15 & 51 & 32 \\
\hline 11 & Die ontwerp van die talentbestuursproses in die organisasie & 3 & 11 & 42 & 44 \\
\hline 13 & Die prestasiebestuur in die organisasie & 1 & 13 & 41 & 45 \\
\hline 15 & Die talentbestuursagteware in die organisasie & 35 & 18 & 21 & 26 \\
\hline 19 & Die assessering van gereedheid vir bevordering in die organisasie & 2 & 18 & 42 & 38 \\
\hline \multirow[t]{2}{*}{21} & Die vroeë identifisering van leierskapspotensiaal in die organisasie & 0 & 9 & 41 & 50 \\
\hline & $\begin{array}{l}\text { Die sterkte van u eie senior bestuurspan in die uitvoer van die volgende } \\
\text { komponente: }\end{array}$ & & & & \\
\hline 42_1 & Talentoptimalisering & 2 & 14 & 44 & 40 \\
\hline $42 \_2$ & Katalisering van verandering & 3 & 15 & 34 & 49 \\
\hline $42 \_3$ & Seniorspanontwikkeling & 8 & 7 & 37 & 49 \\
\hline $42 \_4$ & Selfbegrip en selfbewustheid & 2 & 8 & 24 & 67 \\
\hline $42 \_5$ & Kultuur van hoë prestasie & 1 & 4 & 25 & 70 \\
\hline $42 \_6$ & Kultuur wat talentvolle werknemers waardeer en versorg & 2 & 13 & 29 & 56 \\
\hline $42 \_7$ & Strategiese verhoudingsbou & 1 & 6 & 38 & 55 \\
\hline $42 \_8$ & Die implementering of uitvoer van strategieë & 1 & 4 & 37 & 58 \\
\hline
\end{tabular}

TABLE 3: Variansie-analisetabel vir die toets van die verskille tussen die komponentfrekwensietellings van die verskillende sektore.

\begin{tabular}{|c|c|c|c|c|c|}
\hline Variasiebron & $d f$ & Som van kwadrate & Gemiddeld van kwadrate & $F$ & $P r \geq F$ \\
\hline Tussen sektor & 2 & 290.40105 & 145.20053 & 1.26 & .2879 \\
\hline Foute & 114 & 13147.90000 & 115.33246 & - & - \\
\hline Totaal & 116 & 13438.30105 & - & - & - \\
\hline
\end{tabular}

$d f$, degrees of freedom; $F$, frequency; $P r$, probability.

TABEL 4: Variansie-analisetabel vir die toetsing van die verskille tussen die tevredenheidstellings van die verskillende sektore.

\begin{tabular}{llllll}
\hline Variasiebron & $\boldsymbol{d} \boldsymbol{f}$ & Som van kwadrate & Gemiddeld van kwadrate & $\boldsymbol{F}$ & $\boldsymbol{P r} \geq \boldsymbol{F}$ \\
\hline Tussen sektor & 2 & 1297.12534 & 648.56267 & .0005 & -13 \\
Foute & 114 & 9095.83485 & $\mathbf{7 9 . 7 8 8 0 3}$ & - \\
\hline Totaal & $\mathbf{1 1 6}$ & $\mathbf{1 0 3 9 2 . 9 6 0 1 9}$ & - & - \\
\hline
\end{tabular}

$d f$, degrees of freedom; $F$, frequency; $P r$, probability.

\section{Verskille tussen sektore met betrekking tot die persepsie van hoe gereeld die onderskeie komponente gebruik word (volledigheid)}

Verskille (sien Tabel 3) in die gemiddelde van die komponentfrekwensietellings is gevind tussen die finansiële, vervoer- en mynbousektore, maar die verskille is nie statisties beduidend nie $(p \geq .05)$. Hipotese 1 , naamlik dat daar statisties beduidende verskille bestaan in die tellings behaal op die volledigheid van die komponente wat ingesluit moet word in talentbestuursprogramme in die finansiële, vervoeren mynbousektore in die uitgesoekte Suid-Afrikaanse organisasies, word dus nie deur die data ondersteun nie.

\section{Verskille tussen sektore met betrekking tot tevredenheid met talentbestuursprogramme}

Die gemiddeld van die mynbousektor se tevredenheid is redelik laer bevind as die tevredenheidsvlakke van die finansiële en vervoersektore. 'n Statisties hoogs beduidende verskil ( $p \leq .001$ ) (sien Tabel 4 ) is tussen die tevredenheidstellings van die respondente uit die finansiële, vervoer- en mynbousektore gevind. Hipotese 2, naamlik dat daar statisties beduidende verskille bestaan in die tellings behaal op die tevredenheid van die respondente met die talentbestuursprogramme in die finansiële, vervoeren mynbousektore in die uitgesoekte Suid-Afrikaanse organisasies, word dus deur die data ondersteun.

Om egter te bepaal presies watter van die drie sektore van mekaar verskil, is Tukey se paarsgewyse vergelykingstegniek gebruik. Statisties beduidende verskille is gevind tussen die finansiële sektor en die mynbousektor, asook tussen die vervoersektor en mynbousektor ten opsigte van die tevredenheidsvlakke met die talentbestuursprogramme $(p \leq .05)$. Die respondente van die mynbousektor is minder tevrede met die talentbestuursprogram as die respondente 
van die finansiële en vervoersektore. Daar bestaan egter geen statisties beduidende verskille tussen die finansiële sektor en die vervoersektor ten opsigte van die tevredenheidsvlakke met die talentbestuursprogramme nie $(p \geq .05)$.

\section{Verskille tussen die doeltreffendheid van die sektore se talentbestuursprogramme}

Dit blyk dat daar statisties beduidende verskille $(p \leq .05)$ in die gemiddelde van die doeltreffendheidstelling van die finansiële, vervoer- en mynbousektore bestaan (sien Tabel 5). Hipotese 3, naamlik dat daar statisties beduidende verskille bestaan in die tellings behaal op die doeltreffendheid van die talentbestuursprogramme in die finansiële, vervoeren mynbousektore in die uitgesoekte Suid-Afrikaanse organisasies, word dus deur die data ondersteun.

Met behulp van Tukey se paarsgewyse vergelykingstegniek is bevind dat die finansiële sektor en die mynbousektor statisties beduidend van mekaar verskil $(p \leq .05)$ ten opsigte van die doeltreffendheidstellings van die talentbestuursprogramme in die onderskeie organisasies. Hiervolgens is die finansiële sektor se talentbestuursprogram meer doeltreffend as die mynbousektor se talentbestuursprogram. Daar bestaan egter geen statisties beduidende verskille $(p \geq .05)$ tussen die finansiële sektor en die vervoersektor, of tussen die mynbousektor en die vervoersektor ten opsigte van die doeltreffendheid van die onderskeie talentbestuursprogramme nie.

\section{Etiese oorwegings}

Goedkeuring is van die Universiteit van die Vrystaat se navorsingskomitees verkry om die studie te kon uitvoer.

\section{Potensiële voordele en gevare}

Die voordeel wat respondente verkry het vanuit die studie hou verband met werkstevredenheid. Indien organisasies talent doeltreffend bestuur, sal die talentvolle werknemers meer werkstevredenheid ervaar en dus in die organisasie aanbly. Geen risikos vir respondente was aan hierdie studie verbonde nie.

\section{Werwingsprosedure}

Respondente se deelname aan hierdie studie was vrywillig. Deelnemers kon op enige tydstip uit die studie onttrek.

\section{Ingeligte toestemming}

Die navorser het die doel van die studie, asook die proses, aan die respondente verduidelik, waarna toestemming van die respondente verkry is. Respondente was ten volle ingelig waaroor die studie handel en kon dus ingeligte besluite neem rakende hul deelname aan die studie.

\section{Databeskerming}

Die persoonlike data wat gevra is, is relevant tot die studie en die navorser was deursigtig met die redes waarom persoonlike data gevra is. Respondente is verder verseker van anonimiteit.

\section{Bespreking}

Soos reeds genoem, is die doel van hierdie studie om die doeltreffendheid van bestaande talentbestuursprogramme in uitgesoekte Suid-Afrikaanse organisasies in die finansiële, vervoer- en mynbousektore te evalueer. Die doeltreffendheid van die talentbestuursprogramme berus op hoe gereeld die geïdentifiseerde komponente wat in die talentbestuursprogram teenwoordig moet wees, ingesluit is (volledigheid) en op die tevredenheid van die respondente met die onderskeie komponente in hierdie program. Na aanleiding hiervan kan 'n omvattende lys van vereiste komponente van 'n talentbestuursprogram opgestel word wat Suid-Afrikaanse organisasies kan help met die ontwerp en implementering van 'n doeltreffende talentbestuursprogram.

\section{Opsomming van resultate Volledigheid van talentbestuursprogramme}

Uit die resultate blyk dit dat die meeste komponente wat volgens die literatuur in talentbestuursprogramme ingesluit behoort te word, wel in die programme van die finansiële, vervoer-, en mynbousektore ingesluit is. Die uitsondering is talentbestuursagteware, waar slegs $27 \%$ van al die respondente van mening is dat die organisasie voortdurend van talentbestuursagteware as 'n noodsaaklike komponent in die talentbestuursprogram gebruik maak. Die resultate van hierdie studie dui verder daarop dat terugvoer vir ontwikkelingsdoeleindes, werwing en talentverbintenis die enigste komponente is wat volgens meer as $70 \%$ van die respondente deurlopend in die uitvoering van talentbestuur aangewend word.

Die bevindinge van hierdie studie stem grootliks ooreen met vorige navorsing wat in hierdie verband in organisasies gedoen is. Reflections on Talent Management (2006) het bevind dat, van bykans al die ontwikkelingstegnieke wat organisasies tydens talentbestuursprogramme gebruik, minder as $50 \%$ werklik gebruik word.

Die resultate van hierdie studie toon verder dat prestasiebestuur, afrigting, ontwikkeling en opvolgbeplanning

TABEL 5: Variansie-analisetabel vir die toetsing van die verskille tussen die doeltreffendheidstellings van die verskillende sektore.

\begin{tabular}{llllll}
\hline Variasiebron & $\boldsymbol{d} \boldsymbol{f}$ & Som van kwadrate & Gemiddeld van kwadrate & $\boldsymbol{F}$ & $\boldsymbol{P r} \geq \boldsymbol{F}$ \\
\hline Tussen sektor & 2 & 2789.28947 & 1394.64474 & 3.94 \\
Foute & 114 & 40319.03731 & 353.67577 & - \\
\hline Totaal & $\mathbf{1 1 6}$ & $\mathbf{4 3 1 0 8 . 3 2 6 7 8}$ & - & - & - \\
\hline
\end{tabular}

$d f$, degrees of freedom; $F$, frequency; $P r$, probability. 
volgens meer as 50\% van die respondente (steeds 'n relatiewe lae persentasie) voortdurend gebruik word in die uitgesoekte organisasies. Volgens Wellins en Caver (2006) is die komponente wat die meeste in die talentbestuursprogramme gebruik word prestasiebestuur, afrigting, ontwikkeling en opvolgbeplanning. Die komponente wat die minste gebruik word, is talentbestuursagtewarestelsels, assessering van gereedheid vir bevordering en suksesprofielanalise.

Die bevinding in hierdie studie dat hoëpotensiaalleierskapsontwikkelingsprogramme slegs die 50\%-kerf bereik ten opsigte van die frekwensie van die gebruik daarvan, is 'n bron van kommer aangesien hierdie ontwikkelingsprogramme noodsaaklik is in die huidige sakewêreld waar daar ' $n$ groot tekort aan leiers is (Charan et al., 2001; Gainsford, 2010; Makholwa, 2010; O'Neal \& Gebauer, 2006; Ready \& Conger, 2007). Die bevinding van hierdie studie, naamlik dat die evaluering van die talentbestuursprosesontwerp volgens 'n groot persentasie van die respondente nie voortdurend plaasvind nie, kan 'n invloed op die doeltreffendheid van die talentbestuursprogram hê. Soos reeds genoem, word die talentbestuursproses deur voortdurende ontwikkeling, aanpassing en verandering gekenmerk ten einde te verseker dat die proses in lyn met die organisatoriese strategieë en doelwitte bly. Dus moet die ontwerp van die huidige talentbestuursproses gereeld in oënskou geneem word (Gainsford, 2010; Oehley, 2007).

Die bevinding dat slegs $49 \%$ van die respondente van mening is dat bestuurders skiktyd aan werknemers toestaan, kan die verbintenis van die werknemers tot die organisasie beïnvloed omdat verbintenis gegrond word op gevoelens dat werknemers na waarde geskat word (Du Plooy \& Roodt, 2010; Garger, 1999; Oehley, 2007; Schreuder \& Coetzee, 2011; Sohail et al. 2011).

Dit is kommerwekkend dat ' $\mathrm{n}$ relatiewe klein persentasie van die respondente in hierdie studie van mening is dat lynbestuurders voortdurend as talentbestuurders opgelei word aangesien lynbestuurders die grootste verantwoordelikheid dra om organisatoriese strategieë in resultate om te skakel deur talent in die organisasie te betrek. Talentbestuurders moet oor die nodige vaardighede beskik om talent te bestuur. Dus moet lynbestuurders met die nodige vaardighede toegerus word om talent in die organisasie te kan bestuur (Aquila, 2007; Cantrell \& Benton, 2007; Van Dam, 2008; Wellins et al., n.d.).

Sommige navorsers en menslikehulpbronbestuurders beweer dat die opinie kan bestaan dat die talentpoel ryk sal wees in tye van hoë werkloosheid en dat dit maklik sal wees om die regte persoon vir die regte pos te vind. Dit is egter nie die geval nie. Dit beteken wel dat daar oor die algemeen meer kandidate om elke pos meeding.

Negentien persent (19\%) van die respondente is van mening dat dit deurgaans lyk of die verkeerde persoon in die organisasie aangestel is, naamlik iemand wat nie aan die posvereistes voldoen nie en wat ook nie ontwikkelbaar is nie
(Hardy, 2004; Pauw et al., 2008). Dit is 'n aanduiding dat die talent in die organisasie nie doeltreffend bestuur word nie aangesien talentbestuur behels dat die regte persone met die regte vaardighede in die regte poste geplaas word (Wellins et al., n.d.).

Die resultate van hierdie studie ondersteun die bevinding van Fulmer en Bleak (2008) dat daar te veel op die individu en te min op die span gefokus word aangesien 'n relatiewe klein persentasie van die respondente in hierdie studie beweer dat spanwerk voortdurend in die talentbestuursprogram ingesluit word.

\section{Tevredenheid met talentbestuursprogramme}

Die algehele tevredenheid met die komponente van talentbestuursprogramme is redelik laag (sien Tabel 2), wat korreleer met 'n studie deur Wellins en Caver (2006) waar respondente baie lae tevredenheidsvlakke (minder as 50\%) met die komponente van die talentbestuursprogramme getoon het.

Reflections on Talent Management (2006) dui daarop dat $35 \%$ ('n relatiewe hoë persentasie) van die respondente wat aan die studie deelgeneem het die opinie gehuldig het dat die ontwikkelingsaktiwiteite in die organisasie nie doeltreffend is nie en dat hulle dus nie tevrede was met die ontwikkelingstegnieke in die organisasie oor die algemeen nie. Mentorskap is veral 'n bron van kommer wanneer die lae tevredenheidsvlakke ten opsigte van hierdie komponent in ag geneem word. Daar is moontlik nie genoeg senior werknemers met die regte vaardighede in organisasies om doeltreffende afrigters en mentors vir junior werknemers te wees nie (Hardy, 2004; Mulder, 2007; Pauw et al., 2008; Tucker, Kao \& Verma, 2005; S. Phalatse [persoonlike kommunikasie, Julie 21, 2009]; J. Taljaard [Persoonlike kommunikasie, Julie 16, 2009]; H. van Zyl [persoonlike kommunikasie, Junie 18, 2009]).

Die bevinding dat universiteits- en ander onderrigprogramme lae tevredenheidsvlakke bereik, word deur die navorsing van Wellins en Caver ondersteun (2006). Universiteits- en ander onderrigprogramme alleenlik is nie genoeg nie, maar die doeltreffendheid daarvan word verhoog wanneer dit met genoeg praktiese blootstelling gekombineer word (Wellins \& Caver, 2006; L. Grobler [persoonlike kommunikasie, Julie 13, 2009]; A. van der Zwaard [persoonlike kommunikasie, Julie 03, 2009]; M. van Wyk [persoonlike kommunikasie, Julie 13, 2009]).

Die bevinding dat 'n klein persentasie van die respondente baie tevrede met die suksesprofielanalise in die organisasies blyk te wees, word verder deur onlangse navorsing ondersteun (Reflections on Talent Management, 2006; Wellins \& Caver, 2006). Die komponent van talentbestuursprogramme waarmee die laagste tevredenheidsvlakke in hierdie studie bereik is, is talentbestuursagteware. Talentbestuursagteware is ook volgens Wellins en Caver (2006) ' $n$ komponent waarmee uitsonderlike lae tevredenheidsvlakke bereik 
word. Alhoewel opvolgbeplanning 'n wesenlike praktyk in die organisasies is, is die meeste respondente in hierdie studie nie baie tevrede met die opvolgbeplanningsproses nie. Hierdie bevinding stem ooreen met navorsing deur Wellins en Caver (2006) waar slegs 18\% van die respondente tevrede was met die opvolgbeplanningsproses in die organisasies.

Die bevindinge van hierdie studie, naamlik dat die sterkte van die senior bestuurspan in byna alle areas bevraagteken word, word ondersteun deur'n studie deur Wellins en Caver (2006) wat daarop dui dat minder as $43 \%$ van die respondente in alle areas van mening was dat senior bestuurders in hul organisasies sterk leiers is.

\section{Inferensiële statistiek: Verskille tussen sektore}

Daar bestaan geen statisties beduidende verskille tussen die persepsies van die respondente uit die finansiële, vervoer- en mynbousektore rakende die volledigheid van die talentbestuursprogramme nie. Hierdie bevinding kan 'n aanduiding wees dat organisasies in Suid-Afrika oor die algemeen ' $n$ basiese talentbestuursprogram in plek het. Verder is daar wel statisties beduidende verskille tussen die finansiële sektor en die mynbousektor, asook tussen die vervoersektor en die mynbousektor, ten opsigte van die tevredenheid met die talentbestuursprogramme. Die respondente van die mynbousektor blyk minder tevrede met die talentbestuursprogram as die respondente van die finansiële en vervoersektore te wees.

Volgens die resultate van die studie blyk dit verder dat die finansiële sektor en die mynbousektor statisties beduidend van mekaar verskil ten opsigte van die doeltreffendheid van die talentbestuursprogramme in die organisasies. Hiervolgens is die finansiële sektor se talentbestuursprogram meer doeltreffend as dié van die mynbousektor. Daar bestaan egter geen statisties beduidende verskille tussen die finansiële sektor en die vervoersektor, of tussen die mynbousektor en die vervoersektor, ten opsigte van die doeltreffendheid van die talentbestuursprogramme nie.

\section{Gevolgtrekkings en aanbevelings}

Hierdie studie se bevindinge kan as riglyn gebruik word vir die ontwerp en implementering van talentbestuursprogramme. Dit beteken dat die eerste navorsingsdoelwit van hierdie studie bereik is, naamlik om deur middel van literatuurverkenning en onderhoude 'n teoretiese raamwerk te ontwikkel vir die doeltreffende bepaling van die inhoud en implementering van talentbestuursprogramme in uitgesoekte Suid-Afrikaanse organisasies in die finansiële, vervoer- en mynbousektore. Die resultate van die studie kan as kontrolelys gebruik word om te bepaal of die huidige talentbestuursprogram op standaard is. Indien die talentbestuursprogram meer volledig is ten opsigte van die komponente van sodanige programme en talentbestuurders opgelei en bevoeg is om hierdie programme te bestuur, sal die tevredenheid met die programme aansienlik verhoog.
Die belangrikste aksies wat in ' $n$ talentbestuursprogram ingesluit moet wees, is:

- Die artikulasie van talent wat benodig word om die sakestrategieë uit te voer.

- Die vroeë identifisering van potensiaal binne die talentpoel in die organisasie.

- Die evaluering van gereedheid vir bevordering van talent in die organisasie.

- Die ontwikkeling van talent in die organisasie.

Die minimum komponente wat vir insluiting in 'n talentbestuursprogram aanbeveel word, is die volgende:

- Hoëpotensiaal-leierskapsontwikkelingsprogramme

- Afrigting

- Ontwikkeling

- Terugvoer

- Bevoegdheid/suksesprofielanalise

- Talentbestuursprosesontwerp

- Prestasiebestuur

- Talentbestuursagteware

- Opvolgbeplanning

- Assessering van gereedheid vir bevordering

- Vroeë identifisering van leierskapspotensiaal

- Werwing

- Retensie

- Organisatoriese verbintenis.

Die vereistes waaraan 'n talentbestuursprogram moet voldoen, is soos volg:

- Die doelwitte en strategieë van die organisasie moet die dryfveer wees wat die gehalte en hoeveelheid talent wat die organisasie benodig, bepaal.

- Fokus op die span.

- Beskik oor 'n suksesprofiel.

- Ontwikkel 'n sistematiese en geïntegreerde benadering tot alle ontwikkelingsaktiwiteite.

- Talentbestuur is veel meer as opvolgbeplanning.

- 'n Duidelike onderskeid word tussen potensiaal, prestasie en gereedheid getref.

- Senior leiers moet talent bestuur.

- Verander leiers in talentbestuurders.

- Talentbestuur behels die regte persone in die regte poste.

Die aanbeveling kan gemaak word dat die organisasies in die finansiële, vervoer- en mynbousektore die totale talentbestuursprogram moet hersien, met die uitsondering van die volgende komponente:

- Terugvoer vir ontwikkelingsdoeleindes

- Werwing

- Verbintenis van talent.

Organisasies moet egter spesifiek aandag gee aan die gebruik van talentbestuursagteware tydens talentbestuur aangesien die gebruik van hierdie programme die bestuur van talent in organisasies aansienlik verbeter en vergemaklik.

Die lae tevredenheidsvlakke wat bereik is met die talentbestuursprogramme maak die hersiening van die algehele talentbestuursprogramme in die onderskeie 
organisasies selfs meer dringend. Die resultate van hierdie studie kan gebruik word om die areas waar ontevredenheid met die programme bestaan, te identifiseer.

\section{Implikasies vir bestuur}

Die werkslading van die talentbestuurders, sowel as die talentvolle werknemers, moet hersien word aangesien 'n te groot werkslading sal veroorsaak dat talentbestuur 'n afgejaagde proses word. Verder is dit noodsaaklik dat talentvolle werknemers so vroeg as moontlik in die organisasie geïdentifiseer word omdat die talentpoel in SuidAfrika vinnig besig is om op te droog.

Die laaste aanbeveling is dat soveel as moontlik senior werknemers wat oor die nodige potensiaal beskik, opgelei moet word om mentors en/of afrigters te wees aangesien die probleem in die meeste organisasies ' $n$ tekort aan genoeg bevoegde mentors of afrigters is om junior werknemers op te lei en te ontwikkel. Dit is dus noodsaaklik dat bestuurders persone in poste aanstel wat selfs beter presteer en oor meer potensiaal beskik as hulself om sodoende die kultuur van hoë prestasie te behou en te verbeter. Dit sal genoeg potensiële afrigters en mentors lewer om junior werknemers by te staan om die produktiwiteit van die organisasie te verhoog.

\section{Beperkinge van studie}

Die betroubaarheid van die talentbestuursvraelys is onbekend en is dus ' $n$ beperking van die studie wat in toekomstige navorsing aangespreek moet word.

Verder moet die steekproef van die ondersoek groter wees en meer organisasies insluit sodat die resultate van die studie veralgemeen kan word. Die studie kan egter deur Suid-Afrikaanse organisasies in die finansiële, vervoer- en mynbousektore as 'n riglyn gebruik word om 'n doeltreffende talentbestuursprogram te ontwikkel en te implementeer.

\section{Voorstelle vir verdere navorsing}

Eerstens moet die betroubaarheid van die talentbestuursvraelys vasgestel word. Tweedens moet die steekproef van die studie groter wees en meer organisasies insluit sodat die resultate van die studie veralgemeen kan word. Derdens kan dit tot voordeel van die navorser wees om al die vraelyste elektronies aan deelnemers uit te stuur aangesien die respondente moontlik eerliker kan wees oor hulle houding teenoor die talentbestuursprogram. Deur van e-posdienste gebruik te maak word die moontlikheid dat talentbestuurders 'n vraelys aan 'n spesifieke werknemer kan koppel aansienlik kleiner omdat die respondente die vraelyste direk aan die navorser terugstuur.

\section{Erkenning \\ Mededingende belange}

Die outeurs verklaar dat hulle geen finansiële of persoonlike verbintenis het met enige party wat hulle nadelig kon beïnvloed in die skryf van hierdie artikel nie.

\section{Outeursbydrae}

Die artikel is uit 'n Meestergraad -studie (Master Societatis Scientiae) ontwikkel deur J.P.G. (Universiteit van die Vrystaat). Die artikel is deur J.P.G. (Universiteit van die Vrystaat) onder toesig en leiding van E.S.v.Z. (Universiteit van die Vrystaat) geskryf.

\section{Literatuurverwysings}

Aggerwal, A. (2011). Sampling issues in research methodologies [Steekproefkwessies in navorsingsmetodologieë]. Indian Journal of Medical Specialities, 2(2), 169-172.

Allen, N.J., \& Meyer, J.P. (1990). The measurement and antecedents of affective, continuance and normative commitment to the organization [Die meting en antesedente van affektiewe, voortdurende en normatiewe verbintenis tot die organisasie]. Journal of Occupational Psychology, 63, 1-18. http://dx.doi. org/10.1111/j.2044-8325.1990.tb00506.x

Aquila, A.J. (2007). Key best practices for succession planning. Accounting Today, 21(11), 23.

Berg, B.L. (2004). Qualitative research methods for the social sciences. (5th edn.) Boston: Pearson

Burke, M., \& Kock, R. (2008). Managing talent in the South African public service [Die bestuur van talent in die Suid-Afrikaanse publieke sektor]. Public Personnel Management, 37(4), 457-470.

Cantrell, S., \& Benton, J.M. (2007). The five essential practices of a talent multiplier [Die vyf noodsaaklike praktyke van ' $n$ talentvermenigvuldiger]. Business Strategy Series, 8(5), 358-364. http://dx.doi.org/10.1108/17515630710684475

Charan, R., Drotter, S., \& Noel, J. (2001). The leadership pipeline: How to build the leadership-powered company. San Francisco: Jossey-Bass.

Donaldson, C. (2006). Topping up on talent. Retrieved Januarie 17, 2009, from http:// www.humanresourcesmagazine.com.au/articles/82/0c03dc82.asp

Du Plooy, J., \& Roodt, G. (2010). Work engagement, burnout and related constructs as predictors of turnover intentions [Werksbetrokkenheid, uitbranding en verwante konstrukte as voorspellers van omset-intensies]. SA Journal of Industrial Psychology/SA Tydskrif vir Bedryfsielkunde, 36(1), Art. \#910, 13 pages. http:// dx.doi.org/0.4102/sajip.v36i1.910

Duttagupta, R. (n.d.). Identifying and managing your assets: Talent management. Retrieved September 08, 2006, from http://www.buildingipvalue.com/ 05_ SF/374_378.htm

Ellehuus, C. (2012). Transforming business leaders into talent champions [Transformeer besigheidsleiers in talentkampioene]. Strategic HR review, 11(2), 84.

Fatoki, O., \& Chindoga, L. (2011). An investigation into the obstacles to youth entrepreneurship in South Africa ['n Ondersoek na die struikelblokke vir jeugentrepreneurskap in Suid-Afrika]. International Business Research, 4(2), 161-169. http://dx.doi.org/10.5539/ibr.v4n2p161

Fulmer, R.M., \& Bleak, J.L. (2008). The leadership advantage: How the best companies are developing their talent to pave the way for future success. New York: AMACOM.

Gainsford, J.P. (2010). Die effektiwiteit van talentbestuursprogramme in geselekteerde Suid-Afrikaanse organisasies. Ongepubliseerde meestersgraadverhandeling, Universiteit van die Vrystaat, Bloemfontein.

Garger, E.M. (1999). Holding on to high performers: A strategic approach to retention [Vashou aan hoë presteerders: ' $\mathrm{n}$ Strategiese benadering tot die behoud]. Compensation and Benefits Management, 15(4), 10-17.

Hardy, K. (2004). Self-leadership as a tool in management succession planning. The Public Manager, winter, 41-44.

Hartley, D.E. (2004). Tools for talent [Gereedskap vir talent]. Training and Development, 58(4), 20-22.

Huysamen, G.K. (1996). Methodology for the social and behavioural sciences. Johannesburg: International Thomson Publishing.

Johnson, B.R. (1997). Examining the validity structure of qualitative research [Ondersoek die geldigheidsstrukture van kwalitatiewe navorsing]. Education, 118(3), 282-292.

Liker, J.K., \& Meier, D.P. (2007). Toyota talent: Developing your people the Toyota way. New York: McGraw-Hill.

Makholwa, A. (2010, 24 June). Ageing workforce a worry. Finweek, p. 12.

Mulder, C. (2007, 08 February). Nurture the minority who show potential and desire: If elitism translates into an enhanced skills base, bring it on. Finweek, p. 60.

Neuman, W.L. (1997). Social research methods: Qualitative and quantitative approaches. (3rd edn.). Boston: Allyn and Bacon.

Oehley, A. (2007). The development and evaluation of a partial talent management competency model. Unpublished master's thesis, Stellenbosch Universiteit, Stellenbosch, South Africa.

O'Neal, S., \& Gebauer, J. (2006). Talent management in the 21st century: Attracting, retaining and engaging employees of choice [Talentbestuur in die 21ste eeu: Lok, behou en kry gekose werknemers betrokke]. WorldatWork Journal, 15(1), 6-16.

OPP. (2003). Capitalising on talent. Retrieved September 11, 2006, from http://www. opp.eu.com/uploadedfiles/Capitalising\%20on\%20Talent.pdf 
Patton, M.Q. (2002). Qualitative evaluation and research methods. (3rd edn.) Thousand Oaks, CA: Sage Publications.

Pauw, K., Oosthuizen, M., \& Van der Westhuizen, C. (2008). Graduate unemployment in the face of skills shortages: A labour market paradox [Gegradueerde werkloosheid in die aangesig van vaardigheidstekorte: 'n arbeidsmark paradox]. South African Journal of Economics, 76(1), 45-57. http://dx.doi.org/10.1111/ j.1813-6982.2008.00152.x

Quick, J.C., \& Nelson, D.L. (2009). Principles of organizational behavior: Realities and challenges. (6th edn.). Australia: South-Western CENGAGE Learning.

Ready, D.A., \& Conger, J.A. (2007). How to build a talent factory [Hoe om ' $n$ talentfabriek te bou]. Computer World, 41(24), 30.

Reflections on Talent Management. (2006). Retrieved October 23, 2006, from http:// www.cipd.co.uk/NR/rdonlyres/F473B522-DD49-49E2-9021-59EOBZBDA288/ O/ reftalmanca0306.pdf

SAS Institute Inc. (2009). SAS/IML 9.21 User's Guide. Cary, NC: SAS Institute Inc.

Schreuder, A.M.G., \& Coetzee, M. (2011). Careers: An organisational perspective. (4th edn.). Lansdowne: Juta \& Co.

Sears, D. (2003). Successful talent strategies: Achieving superior business results through market-focused staffing. New York: AMACOM.

Sohail, N., Muneer, A., Tanveer, Y., \& Tariq, H. (2011). Losing your best talent: Employee retention the dilemma of the textile industry [Verloor jou beste talent: Werknemerretensie die dilemma van die tekstielindustrie]. Interdisciplinary Journal of Contemporary Research in Business, 3(8), 896-906.
Tett, R.P., \& Meyer, J.P. (1993). Job satisfaction, organizational commitment, turnover intention and turnover: Path analysis based on meta-analytic findings [Werkstevredenheid, organisatoriese verbintenis, omet-intensie en omset: Padanalise gebaseer op meta-analitiese bevindinge]. Personnel Psychology, 46(2), 259-293. http://dx.doi.org/10.1111/j.1744-6570.1993.tb00874.x

Tucker, E., Kao, T., \& Verma, N. (2005). Next-generation talent management: Insights on how workforce trends are changing the face of talent management [Volgendeon how workforce trends are changing the face of talent management [Volgendegenerasie talentbestuur: Insigte in hoe arbeidsmarktendense talentbestuur
verander]. Business Credit, 106(7), 20-27.

Van Dam, N. (2008). Developing scalable business coaching [Ontwikkel meetbare besigheids-afrigting]. Chief Learning Officer, 7(2), 14.

Van Schalkwyk, S., Du Toit, D.H., Bothma, A.S., \& Rothmann, S. (2010). Job insecurity, leadership empowerment behaviour, employee engagement and intention to leave in a petrochemical laboratory [Werkssekuriteit, leierskapsbemagtigingsgedrag werknemerbetrokkenheid en intensie om te bedank in ' $n$ petrochemiese laboratorium]. SA Journal of Human Resource Management/SA Tydskrif vir Menslikehulpbronbestuur, 8(1), Art. 234, 7 pages. http://dx.doi.org/10.4102/ sajhrm.v8i1.234

Wellins, R.S., \& Caver, K. (2006). DDI survey findings at the Conference Board 2006 Talent Management Strategies Conference. Retrieved October 15, 2006, from http://www.ddiworld.com/pdf/ddi_2006talentmanagementstrategiesconferen ce _es.pdf

Wellins, R.S., Smith, A.B., Paese, M.J., \& Erker, S. (n.d.). White Paper: Nine best practices for effective talent management. Retrieved November 01, 2006, from http://www.ddiworld.com/pdf/ddi ninebestpracticetalent management_wp.pdf 